\title{
Right to Information Act; ultimatum for an accountable healthcare system
}

\author{
Perera UCP \\ Department of Forensic Medicine, Faculty of Medicine, University of Ruhuna, Galle, Sri Lanka.
}

Correspondence: Dr.UCP Perera

e-mail:clifford@med.ruh.ac.lk

The right of access to information held by public authorities is a guaranteed fundamental right of any Sri Lankan under the $19^{\text {th }}$ amendment to the Constitution (1). To give effect to this right the parliament adopted the Right to Information Act No 12 of 2016 (RTI Act) which gives the legal framework for access to information held by public authorities. The RTI Act came into force on the $4^{\text {th }}$ August 2016.

The Act received high levels of support from both civil society and government, and was enacted unanimously by the Parliament. The Act's successful passage was the culmination of a history of prior attempts to enact Right to Information (RTI) legislation since the mid-1990s, many of which failed to progress beyond draft stage.

The preamble to the RTI Act states that it aims to 'foster a culture of transparency and accountability in public authorities', thereby enabling citizens of Sri Lanka to 'fully participate in public life through combating corruption and promoting accountability and good governance' (2). It grants Sri Lankan citizens the right of access to information in the possession, custody or control over an estimated 4,500 public authorities (3). The provisions of the Act pertaining to the supply of information are due to come into effect within a period of six months after its certification, and no later than one year since the same (4).

In October 2016, the Ministry of Parliamentary Reforms and Mass Media directed ministries, provincial councils and other government departments to: (i) nominate Information Officers for all institutions falling under their purview, and (ii) archive and maintain information and records. Furthermore, the Ministry issued a gazette notification stating that the RTI Act will come into operation on $3^{\text {rd }}$ February 2017 (5). Accordingly, all public authorities falling under the scope of RTI are now expected to be able to receive and process RTI requests. Under its powers in terms of section 41(2) of the RTI Act, the Ministry passed a series of Regulations governing RTI implementation. These Regulations set out the procedure on matters including: (a) the initiation of information requests, (b) rejection of information requests, and (c) continuous proactive disclosure.

This is a brief attempt to analyse the content of RTI Act No. 12 of 2016 and to realize the impact of it to the healthcare sector.

Sri Lanka's RTI Act is regarded as the third strongest in the world, and the strongest in South Asia (6). Consultations with Civil Society Organizations (CSO) actors during all stages in the drafting process ensured that the Bill was compliant with international standards. For instance, CSOs played a role in ensuring that provisions relating to the narrow framing of denial clauses, and the proactive disclosure of information by Ministries were incorporated in the RTI Act. Moreover, the technical expertise of CSO actors involved in the Drafting Committee and the RTI Advisory Task force ensured that progressive elements of the Bill, such as the public interest override clause, were retained in the text during the drafting process.

\section{Health Sector and RTI Act}

The Act gives every citizen the right to access information that is in the possession, custody or control of a public authority. 'Information', under the Act includes a wide variety of material such as 
records, documents, memos, emails, opinions, advices, press releases, memorandom, circulars, orders, log books, contracts, reports, papers, samples, models, correspondence, draft legislation, book, plan, map, drawing, diagram, pictorial or graphic work, photograph, film, microfilm, sound recording, video tape, machine readable record, computer records and other documentary material (7). Accordingly the multiple formats of documents and material currently used in the healthcare sector including ministry circulars, all types of patient registers, duty rosters, guidelines / protocols / flow charts, bed head tickets, theatre notes, ICU records, observation charts, patient investigation reports, radiographs, ultra sound, CT \& MRI scans / reports, all types of retained human tissues, all types of medico-legal forms and reports, night reports, incident reports and disciplinary inquiry reports will directly come under the interpretation of 'Information' of the RTI Act. Further the documents and material pertaining to health related activities / policies / research maintained at all medical faculties and in organizations such as Sri Lanka Medical Council (SLMC) and Sri Lanka Nursing Council (SLNC) will also come under RTI Act. 'Public authorities' under the Act include ministries, public corporations, a company where the state owns in excess of twenty-five per cent of the shareholding, and higher educational institutions that are substantially funded by the state (7).

The impact of the RTI Act on the health sector is not yet being discussed in detail specially at ground levels. However a careful analysis of the content of the Act would definitely reveal many areas pertaining to health information management, which needs to be streamlined by the health authorities rapidly. Two such areas are:

- Preservation of medical records

- Release of confidential medical information

We wish to consider the issue of preservation of medical records and the requirement of RTI Act briefly as an eye opener. The S.7 of the RTI Act refers to the maintenance and preservation of records in public institutions, of which the healthcare institutions are an important stakeholder.

"S.7 Public authorities to maintain and preserve its records
(3) All records being maintained by every public authority, shall be preserved -

(a) in the case of those records already in existence on the date of coming into operation of this Act, for a period of not less than ten years from the date of coming into operation of this Act; and

(b) in the case of new records which are created after the date of coming into operation of this Act, for a period of not less than twelve years from the date on which such record is created."

These requirements are distinctly deviant from the current hospital practice. According to DGHS General Circular: No.01-10/2002 dated 30 $0^{\text {th }}$ April 2002 (8), 'Heads of Institutions should preserve the bed head tickets (BHTT) related to medico legal work in a separate section under a separate register in the Record Room of the hospital for a minimum period of 10 years'. It has no reference to other BHTT. As we are aware, all other BHTT in state hospitals are kept only for 5 years. The requirement of RTI Act is to preserve all previous BHTT (documented prior to its enactment) for a period not less than ten years.

However since the RTI Act is in force, it is required to streamline the time period of preservation of medical records in all hospitals according to the prescribed conditions. Therefore it is essential to issue a new circular by DGHS urgently describing essential instructions to follow when maintaining medical records (including BHTT) and clarifying all the above stated points of RTI Act as this issue would necessarily come up in court cases related to hospitalized patients / victims in the near future.

Furthermore, the health sector will be required to categorize health / medical information according to levels of accessibility and develop mechanisms of providing accessible health information to public on request in the future as per the provisions of RTI Act.

\section{Compliance with other regulations / laws}

The Section 4 of the RTI Act stipulates that the Act supersedes all other laws in Sri Lanka. Therefore, it will be necessary that current laws that are inconsistent with the Act be amended to the extent of their inconsistency. Such amendments will strengthen the implementation of and compliance 
with the RTI Act, particularly in a context of a prevailing culture of secrecy around the supply of government information. The Official Secrets Act, No. 32 of 1955 (Official Secrets Act), Sri Lanka Press Council Law, No. 5 of 1973 (Press Council Law), National Archives Act No 48 of 1973 \& Declaration of Assets and Liabilities Law No. 1 of 1975 (Assets and Liabilities Law) are some of the legislative enactments which should be amended accordingly.

\section{Revision of the Establishments Code of Sri Lanka, 1971}

The Establishments Code of Sri Lanka, 1971 (Establishments Code) regulates the conduct of public officers. Paragraph 6 of Chapter XLVII of the Code permits a Secretary to a Ministry to take disciplinary action against officers who disclose information that 'may cause embarrassment to the government as a whole, or any government department, or officer'. These penalties are applicable even if the information disclosed was a statement of fact.

This provision directly contravenes the whistleblower protection available under section 40 of the RTI Act, thereby disincentivising public officers from disclosing instances of corruption and mismanagement in good faith. Under Section 40 of the RTI Act, an officer disclosing information that is permitted to be disclosed under the RTI Act is protected from disciplinary sanction, even if the disclosure may result in subsequent embarrassment caused to the government. The Section 40 is hence designed to protect officers who disclose instances of fraud or misappropriation within their ministries. In this context, it is imperative that the Establishment's Code be amended to reflect the whistle-blower protection available under Section 40 of the RTI Act. This amendment will increase the assurance among public officers that they will not be sanctioned for disclosing information on wrongdoing.

Similarly, the Establishment Code prevents a government agency from issuing a copy of a letter it received from another government agency to any private person. It also prohibits the issuance of a certified copy of a letter received or reply sent by the government to anyone other than to the person who wrote the letter, unless there is a judicial order to release it. The Establishment Code contravenes the time frame stipulated in the Section 7.3 of the RTI Act for information preservation and disposal. The amendments to the establishment code do not need legislative enactments and as such they can be made through directives from the Public Service Commission and the Ministry of Public Administration and Management.

It would be appropriate to include a new chapter to the Establishment Code introducing proactive disclosure as a performance obligation of the public authorities. The new chapter of the Establishment Code may include a minimum standard for proactive disclosure based on identified principles.

\section{Obtaining information under the Act; Information Requests}

Every public authority is mandated to appoint an Information Officer, who is tasked with receiving and processing information requests (9). Information Officers are required to decide on information requests within a fourteen-day period as per S. 25(1). If the Information Officer decides that the information requested could be disclosed, he or she is required to grant access to such information within a period of fourteen days according to $\mathrm{S}$. 25(2). Under Section 25(5) of the RTI Act this fourteen-day period can be extended to a maximum of twenty one days, in the event the volume of documentation is high. Moreover, in the event the information request relates to the life or liberty of a person, this information is required to be supplied to the individual within a period of forty-eight hours under Section 25(3) of the RTI Act.

In the event the Information Officer decides to deny the individual's information request, he or she must do so in terms of the specific grounds listed under the Section 5(1) of the Act. For example, information requests may be denied if the disclosure undermines the defence of the state, causes serious prejudice to the economy of Sri Lanka, or harms the competitive position of a third party. However, even if the information requested falls under one of the specified grounds for denial under the Act, the Information Officer is required to disclose the information if the public interest associated with the information outweighs the harm that is likely to 
be caused by disclosure as per Section 5(4). Individuals who are dissatisfied by the decision of an Information Officer have the right to appeal first to a Designated Officer appointed by the Ministry, then to the independently appointed Information Commission, and finally to the Court of Appeal as per Sections 31, 32 \& 34(1). The Ministry of Health has already notified its 'Information Officers' in the Ministry website and also provided access to various RTI forms through the RTI website (10). It is also apparent from the RTI Commission website that public has already requested / appealed for provision of copies of medico-legal reports from 'Information Officers'(11).

\section{Regulations Promulgated by the Ministry of Parliamentary Reforms and Mass Media}

In accordance with the RTI Act, the Ministry of Parliamentary Reforms and Mass Media recently promulgated regulations to implement the law, including Regulation No. 20 concerning Proactive Disclosure of Information (12). There are several important aspects to this regulation. The regulation:

i. stipulates that public authorities should proactively disclose information 'routinely', rather than in an ad hoc manner, thereby increasing the frequency of disclosure;

ii. requires that the information to be proactively disclosed is 'at a minimum', thereby establishing a base standard which public authorities should seek to exceed;

iii. stipulates the described information should be disseminated by 'digital or electronic format', ensuring that the information reaches the broadest possible audience, and results in greater transparency and accountability;

iv. identifies sixteen categories of information that must be proactively disclosed, ranging from information about the organisation and function of a public authority to information on subsidies and public procurements;

v. encourages public authorities to include in their biannual reports required under Section 8 'such information as may be of interest to the public', to limit the need to file RTI requests for such information; vi. provides that a recipient may challenge the accuracy or age of the proactively disclosed information before the head of the public authority or the RTI Commission.

The above Regulation issued in terms of the RTI Act expands the scope of proactive disclosure in the Act and gives the principle its full effect.

The government could consider reviewing the sixteen categories of information listed in Regulation 20 after a specified time period, to ensure an assessment of whether the list needs addition or revision. The RTI Commission could establish a joint government-civil society committee to contribute to that review and consider additional categories of information, and develop guidelines for public authorities for further proactive disclosure.

\section{Offences and Protection}

Any person who deliberately obstructs the provision of information under the RTI Act, tampers with information, or fails to give effect to a decision by the Information Commission commits an offence under the RTI Act (13). Meanwhile, whistle-blower protection is available under Section 40 of the Act. The provision prevents the punishment (disciplinary or otherwise) of a public officer that discloses information that is permitted to be disclosed under the Act.

\section{Global Norms and Practice}

Article 19 of the Universal Declaration of Human Rights holds that the right to freedom of expression includes the freedom 'to seek, receive and impart information' (14). The International Covenant on Civil and Political Rights (ICCPR), to which Sri Lanka is a party, contains the same provision and creates a legally-binding obligation on signatories. The UN Human Rights Committee, which monitors the implementation of the ICCPR, has subsequently adopted General Comments to provide practical guidance to states on meeting their obligations under Article 19. General Comment 10, adopted in 1983, reiterated that states must protect freedom of expression including the 'freedom' to 'seek' and 
'receive' (information and ideas) 'regardless of frontiers' and in whatever medium. 'However, it did not address proactive disclosure (15). In 2011, with scores of RTI laws in effect across the globe, the Human Rights Committee adopted a more comprehensive General Comment 34, replacing General Comment 10, that addresses states' obligation concerning the 'right of access to information' and proactive disclosure, specifically:

To give effect to the right of access to information, States parties should proactively put in the public domain Government information of public interest. States parties should make every effort to ensure easy, prompt, effective and practical access to such information.

States parties should also enact the necessary procedures, whereby one may gain access to information, such as by means of freedom of information legislation (16).

\section{Regional Norms and Practice}

With its new RTI Act, Sri Lanka joins the community of one hundred and seventeen nations with right to information laws (17). It is the latest South Asian country to adopt a RTI law; only Bhutan remains without one. Many countries in the region, including India, Bangladesh, and Nepal, have comprehensive proactive disclosure provisions in their RTI legislation (18). In Bangladesh, the information commission actually issues the disclosure regulations (19). While not specifically addressing proactive disclosure, right to information commissioners and ombudsmen in Bangladesh and Pakistan have reported many challenges in ensuring public authorities' compliance with their orders, while their Nepalese counterparts indicate substantial compliance (20). India's RTI Act contains 'Obligations of Public Authorities', which require such authorities to first maintain their records, and also to publish at least sixteen different categories of general information about the organisation, function, powers, and rules of the authority, its advisory councils, budget, subsidies, and recipients of concessions (21).

\section{Conclusions}

RTI is a powerful tool that can deliver significant social benefits. It can provide a strong support to democracy and promote good governance, by empowering the citizen's ability to participate effectively and hold government officials accountable. Rather than just providing information, RTI Act in most of the countries has served to be an effective watchdog ensuring all those coming in purview of the Act to work in accordance with rules and regulations, without any irregularities.

Thus, the RTI Act demands a paradigm shift in the relations between the citizens and the public institutions including healthcare institutions. At the same time the RTI Act empowers the public officials including healthcare workers at all levels to be more responsive and accountable. In fact, the proper implementation of the RTI Act would increase the government transparency and integrity of the public officials who wish to resist from being subject to undue interferences in discharging their duties.

\section{References}

1. The Constitution of the Democratic Socialist Republic of Sri Lanka Revised Edition 2015. [statute on the internet]. Available from: http://www.parliament.lk/files/pdf/ constitution.pdf [Accessed 15.07.2018].

2. Right to Information Act No. 12 of 2016. Preamble.

3. RTI, lifting the curtain of secrecy. The Daily News [newspaper on the internet]. 2016 October 4. Available from: http://dailynews.lk/2016-10-03-193000/features/ 94810 [Accessed 15.07.2018].

4. Right to Information Act No. 12 of 2016. Section 1(3).

5. The Gazette of the Democratic Socialist Republic of Sri Lanka. Extraordinary. No. 2002/42 published on 20 January 2017.

6. Centre for Law and Democracy. 'Sri Lanka jumps to third place globally on the RTI rating', 10 February 2017, Available from: [Accessed 15.07.2018].

7. Right to Information Act No. 12 of 2016. Section 43.

8. Director General of Health Services Sri Lanka. General Circular: No.01-10/2002 dated $30^{\text {th }}$ April 2002.Guidelines for Examination of patient's for Judicial Purposes.

9. Right to Information Act No. 12 of 2016. Section 23(1). 
10. Government of Sri Lanka. Ministry of Health, Nutrition and Indigenous Medicine. Information Officers. Available from: http://www.health.gov.lk/moh_final/english/ public/elfinder/files/StaffNotices/2017/NewAct-122016Information.pdf. [Accessed 15.07.2018].

11. Thilak Ranjith Silva V. Sri Lanka Police-Headquarters. Right to Information Commission of Sri Lanka RTIC Appeal(In-Person)/142/2018.

12. The Gazette of the Democratic Socialist Republic of Sri Lanka. Extraordinary. No. 2004/66 published on 3 February 2017.

13. Right to Information Act No. 12 of 2016. Section 39(1).

14. Universal Declaration of Human Rights. Available from: http://www.ohchr.org/EN/UDHR/Pages/Language.aspx? LangID = eng and International Covenant on Civil and Political Rights. Available from: http://www.ohchr.org/ EN/ProfessionalInterest/Pages/CCPR.aspx [Accessed: 15.07.2018].

15. UN Office of the High Commissioner for Human Rights. General Comment No. 10: Freedom of Expression (Article 19) 29/06/1983.

16. UN Human Rights Committee. International Covenant on Civil and Political Rights: General comment No. 34; Article 19: Freedoms of opinion and expression, $\mathrm{CCPR} / \mathrm{C} / \mathrm{GC} / 34,11$ September 2011.
17. Chronological and Alphabetical lists of countries with FOI regimes. Available from: www.freedominfo.org [Accessed 15.07.2018].

18. The Asia Foundation. Citizens' Access to Information in South Asia: Regional Synthesis Report, August 2014, p.16. Note that two provinces in Pakistan - Punjab and Khyber Pahtunkhwa - have passed RTI legislation and established independent commissions. There are two draft bills at the national level; they draw to some degree on these provinces' legislation.

19. Standards for Proactive Disclosure Recommended. Available from: http://www.freedominfo.org 19 February 2013. [Accessed 15.07.2018].

20. The Asia Foundation. Citizens' Access to Information in South Asia: Regional Synthesis Report. 2014 August 29-30.

21. Government of India. Right to Information Act No. 22 of 2005. Section 4, as modified up to $1^{\text {st }}$ February 2011. 